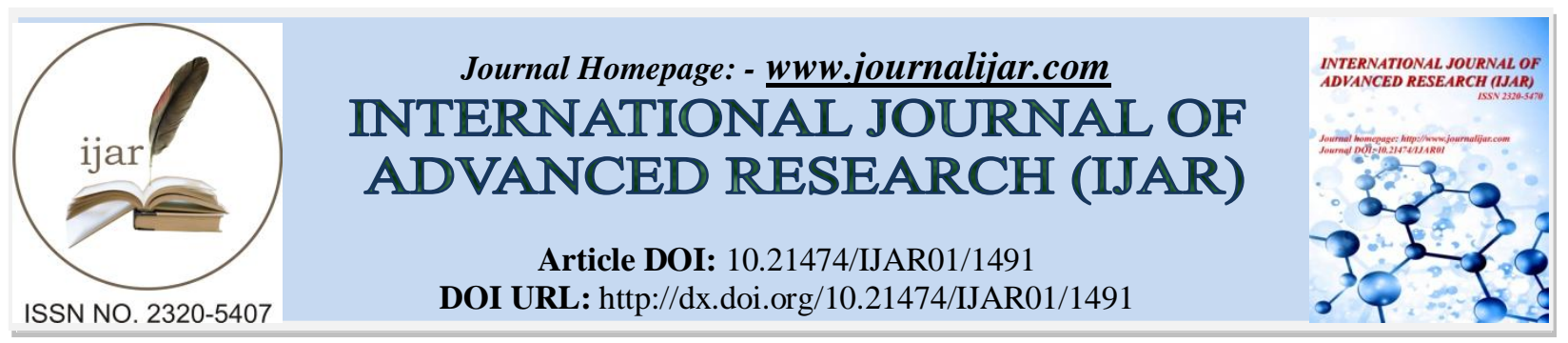

RESEARCH ARTICLE

\title{
STATUS OF DISTRICT PLANNING COMMITTEES FORMATION IN INDIA.
}

\author{
Rajni Kumari. \\ Research Scholar, Department of Political Science, M.D. University, Rohtak-124001(Haryana)
}

\section{Manuscript Info}

Manuscript History

Received: 15 July 2016

Final Accepted: 19 August 2016

Published: September 2016

Key words:- Decentralised

Planning, District Planning

Committee, Article 243ZD, $73^{\text {rd }}$

CAA

\section{Abstract}

This paper concerns with the District Planning Committees and measures taken by Planning Commission, Ministry of Panchayat Raj to activate the formation of DPC's in different states which is always be a desirable goal ever since the inception of developmental planning in India.

\section{Introduction:-}

The institution of District Planning Committee as envisaged in the $73^{\text {rd }}$ Constitution Amendment Act ( $73^{\text {rd }}$ CAA) is the realisation of consistent and conscious effort towards decentralised planning since the process of planned development began in the country. The desire for decentralised planning was first expressed way back in the first five year plan (1951-56), when it was suggested to break the planning process into national, state, district and local community levels. However, the idea was given a concrete shape with the establishment of the District Development Council to consolidate plans prepared at the village level through a participative process. The newly established Panchayat Institutions at the village, block and district level were to help prepare these plans. However, their role and resources were not clearly defined and as a consequence the planning process at the grassroots level suffered.

The Administrative Reforms Commission in its report of 1967 stressed on the need for meaningful planning at the district level especially focusing on local variations in development patterns. Consequently, the Planning Commission issued guidelines for district planning in 1969, which led to several states formulating district plans. However, the exercise remained disjointed from the annual planning process in most states. The widespread suppression and curtailment of powers of Local Self Governance institutions across the states through the late 1960s and 70s led to the choking of district planning process as well. The problem was examined again in 1984 through the Working Group on District Planning headed by C.H. Hanumantha Rao. The Working Group recommended greater decentralisation of functions, powers and resources for meaningful district planning. Other notable recommendations on strengthening planning and administration at the district level came from the G.V.K. Rao Committee on Administrative Reforms for Rural Development (1985) and the Sarkaria Commission for Centre-State Relations (1988).

However, all these efforts at strengthening decentralised planning were met with consistent failure due to several reasons. The weak nature of Local Self Governance Institutions was one of the main causes. A second major cause was the continuous growth and multiplication of sectoral departments and parastatal bodies along with vertical planning, development of sector-specific schemes and vertical rather than horizontal flow of plan funds. Given this 
background of efforts at decentralised planning in India, the $73^{\text {rd }}$ and $74^{\text {th }}$ Amendments were milestones since they provided the much needed constitutional legitimacy to local governance institutions, defined their functional domains and provided for financial devolution to these institutions. The $74^{\text {th }}$ CAA also mandated the establishment of District Planning Committee (DPC) as the formal body for preparation of the District Development Plan by consolidating the plans prepared by the villages and towns in the district.

It is a matter of concern that even after the lapse of 15 years since the amendments were made, decentralised planning is yet to become effective in the country. While most states carried out amendments of their respective state acts in conformation of the $73^{\text {rd }}$ and $74^{\text {th }}$ Amendments, the implementation of the provisions was not uniform in all cases. Setting up elected bodies in local self-governance institutions was carried out, and State Finance Commissions were also formed to provide for financial devolution to these bodies. However, formation of DPCs was one of the neglected aspects.

The issue of decentralised planning was discussed in the Second Round Table Meeting of State Ministers of Panchayati Raj held in Mysore in 2004. The recommendations that emerged from the Meeting included the resolution for constituting DPCs in all states by the end of 2004-05. The Planning Commission was also requested to ensure that the Eleventh Plan is based on consolidation of district plans prepared through DPCs. The Expert Group for Planning at the Grassroots Level chaired by V. Ramachandran was set up in 2005 and set forth an action plan in order to strengthen participatory planning in the Eleventh plan process. It noted with concern the fact that several states had not set up DPCs even after the resolution taken in the Second Round Table. The Group laid out detailed guidelines for the district level planning process and the role of DPCs therein.

Planning Commission took action on these proposals and communicated to the States that the approval of Annual plan proposals for 2006-07 will be contingent upon the constitution of DPCs in all the districts. The Annual Plan Proposals must give details of the total fund availability from various sources down to the Panchayat level. They must indicate the detailed deployment of funds received from various sources among the districts and must also explain the criteria followed for allocating the resources. The preparation of annual planning exercise under the Eleventh plan is thus expected to activate the process of district planning across all the states.

Another significant measure to push for the activation of DPCs is the linking of access to the Backward Region Grants Fund (BRGF) scheme. It is a semi-tied fund available to 250 selected backward districts with the purpose of catalysing development by providing infrastructure, promoting good governance and agrarian reforms, and capacity building for participatory district planning. In order to avail BRGF funds, states are required to establish DPCs as per article 243ZD, which will consolidate plans prepared by PRIs and ULBs in the district. These plans will put together resources from various existing schemes and channelise them to Panchayats on the basis of the district plan. BRGF funds will be used by the Panchayats for gap filling and to converge and add value to other programmes, which provide much larger resources to the same districts. The formula for disbursement of BRGF funds within the district will also be derived at the local level. Decentralised planning is thus at the core of this programme.

\section{Status of DPC Formation across States:-}

DPCs should be constituted as per Article 243 ZD in all states except Jammu \& Kashmir, Meghalaya, Mizoram, Nagaland and the NCT of Delhi. All states must accordingly enact legislations for constitution of the DPCs and issue notifications bringing them into effect. The Expert Group Report of 2006 also carried out a status check on the constitution of DPCs across the states. Things have not changed significantly since then. Their findings for 19 major states, updated to the present, are listed in the table below:

In Andhra Pradesh, Elections to DPC were conducted in July 2007. Government have also nominated four members to each DPC as required under the Act. The elections to DPC in Andhra Pradesh are conducted by State Government but not the State Election Commission. Under the law, it is the ZP Chairperson who is to chair the DPC. In Assam, DPC Constituted in all non-sixth schedule districts. The Chairperson of the ZP Chairs the DPC. In Bihar, DPC is chaired by Zila Parishad Adhyakshas and the DDC is the member secretary. In Chhattisgarh, DPC Constituted with Minister as Chairperson of DPC. The State Government issued guideline under Section 11 of the Act for district planning. $4 / 5^{\text {th }}$ of the members are elected from among the elected representatives of Zila Panchayat and Municipalities. The Chairperson of a DPC can be an in charge Minister from Chhattisgarh and the Collector is the Member-Secretary. 
In Gujarat, DPC Constituted with the in charge Minister as the chairperson and the District Panchayat President as Vice-chairperson as per the Gujarat District Planning Committees Act,2008. In Goa, The Government has constituted District Planning Committee for each District in Goa. The Adhyaksha of the Zilla Panchayat is the ExOfficio Chairman and the Chief Executive Officer of the Zilla Panchayat is the Ex-Officio Member Secretary of the District Planning Committee.

In Haryana, DPC Constituted in all districts. The Urban Development Department Haryana has published a Notification with regard to constitution of District Planning Committees, pursuant to which Constitution of all District Planning Committees have been got completed. In Himachal Pradesh, DPC Constituted with Minister as Chairperson of DPC. In Jharkhand, the Local body elections yet to be held. There is a provision under the law for District Planning Committees (DPCs). DPCs have not been constituted. Provisions for Standing Committees in Panchayats for planning and implementation of allotted subjects exist under the Act. Jharkhand is a unique case in the sense that the $73^{\text {rd }}$ and $74^{\text {th }}$ CAAs have not been implemented at all, and elections to local bodies are yet to be held in the state. This however does not mean that district planning is not being carried out. There is in place a District Planning Unit headed by a District Planning Officer, again whose job is to allocate plan funds arriving to the district under various Central and State schemes, such as MPLAD and MLALAD. Little effort is made to carry out any concrete planning at any village or town level in the district. The District Planning Unit is not unique to Jharkhand and exists in most states as the administrative structure for routing of plan schemes at the district level.

In Karnataka, DPC Constituted with President ZP as Chairperson. In Kerala, DPC Constituted with Chairman District Panchayat as Chairperson. In Madhya Pradesh, DPC Constituted with district-in-charge Minister as Chairperson of DPC. In Maharashtra, DPC Constituted with district-in-charge Minister as Chairperson of DPC and the District Collector as the member-secretary. In Manipur, District Planning Committees have been constituted under Section 96 of the Manipur Panchayati Raj Act, 1994 with the Adhayaksha of the Zilla Parishad as the Chairperson. However, elections are yet to take place as provided in the Act. The State Government of Manipur has undertaken to complete the elections for the elective posts of the District Planning Committee. In Orissa, DPC Constituted in all 30 districts with Minister as Chairperson. In Punjab, DPC Constituted with Ministers as chairperson/vice-chairperson. In Rajasthan, DPC Constituted with Chairman District Panchayat as Chairperson. In Sikkim, DPC Constituted. DPC is chaired by the elected chairperson of the Zilla Panchayat. The District Development officer-cum-Panchayat officer (Member Secretary) All ZP members are members of DPC.

In Tamil Nadu, DPC Constituted with Chairman District Panchayat as Chairperson. In Tripura, DPCDPC has been constituted for the BRGF District, i.e. Dhalai District headed by one Executive Member of the Tripura Tribal Areas Autonomous District Council (Sixth Schedule areas) as Chairman with the concurrence of the Ministry of Panchayati Raj, Government of India. In Uttar Pradesh, District Planning Committee Act was enacted and Notified on July 29,1999. DPC has been constituted for 70 districts as per the District Planning Committee (amendment) Act 2007, with the in charge minister as the chairperson. Earlier the Minister-in-Charge of the district was the Chair of the DPC, and there were two Deputy Chairpersons - the ZP president and the CEO of the Municipality within the district. In Uttarakhand, the DPMC is the existing structure for district level planning. However, the state government has agreed to the constitution of DPCs and a set of guidelines for DPC formation has been issued. These were submitted to the Governor for approval and as a consequence Uttarakhand District Planning Committee Act, 2007 has been passed. The DPCs are to be chaired by a Minister nominated by the State Government and the District Magistrate is the ex-officio member. The Chief Development Officer of the district is the secretary of the committee. However, no DPCs have been constituted so far. The SEC has the superintendence, direction and control of preparations of electoral roll and conduction of election. In West Bengal, DPC Constituted with Chairman District Panchayat as Chairperson.

\section{Conclusion:-}

Most of the major states have constituted DPCs as per the information available. State legislations to constitute DPCs have been enacted in all states considered here. The large and conspicuous omissions, where DPCs have not yet been constituted, include Uttarakhand and Jharkhand. However, this does not guarantee that the DPCs are functional to the same extent in all districts. 


\section{References:-}

1. Status and functioning of District Planning committee in India, PRIA, New Delhi, November 2009.

2. Punjab Update Bureau; December 12, 2014.

3. Economic and Statistical Organisation Planning Department, Haryana, Chandigarh, 2005.

4. Kannan, K.P.(2000): “People`s Planning”, Kerala`s Dilema, Seminar, 485.

5. M. Gopinath Reddy, S. Rama Chandra Reddy, " Decentralised Planning process in Andhra Pradesh- A Later Starter“, Indian Journal of Public Administration, Vol LVI, No. 4, 933-51, October-December 2010. 